\title{
Long-Term Endothelial Cell Loss in Patients with Artisan Myopia and Artisan Toric Phakic Intraocular Lenses
}

Citation for published version (APA):

Jonker, S. M. R., Berendschot, T. T. J. M., Ronden, A. E., Saelens, I. E. Y., Bauer, N. J. C., \& Nuijts, R. M. M. A. (2018). Long-Term Endothelial Cell Loss in Patients with Artisan Myopia and Artisan Toric Phakic Intraocular Lenses: 5- and 10-Year Results. Ophthalmology, 125(4), 486-494. https://doi.org/10.1016/j.ophtha.2017.08.011

Document status and date:

Published: 01/04/2018

DOI:

10.1016/j.ophtha.2017.08.011

Document Version:

Publisher's PDF, also known as Version of record

Document license:

Taverne

Please check the document version of this publication:

- A submitted manuscript is the version of the article upon submission and before peer-review. There can be important differences between the submitted version and the official published version of record.

People interested in the research are advised to contact the author for the final version of the publication, or visit the DOI to the publisher's website.

- The final author version and the galley proof are versions of the publication after peer review.

- The final published version features the final layout of the paper including the volume, issue and page numbers.

Link to publication

\footnotetext{
General rights rights.

- You may freely distribute the URL identifying the publication in the public portal. please follow below link for the End User Agreement:

www.umlib.nl/taverne-license

Take down policy

If you believe that this document breaches copyright please contact us at:

repository@maastrichtuniversity.nl

providing details and we will investigate your claim.
}

Copyright and moral rights for the publications made accessible in the public portal are retained by the authors and/or other copyright owners and it is a condition of accessing publications that users recognise and abide by the legal requirements associated with these

- Users may download and print one copy of any publication from the public portal for the purpose of private study or research.

- You may not further distribute the material or use it for any profit-making activity or commercial gain

If the publication is distributed under the terms of Article 25fa of the Dutch Copyright Act, indicated by the "Taverne" license above, 


\section{Long-Term Endothelial Cell Loss in Patients with Artisan Myopia and Artisan Toric Phakic Intraocular Lenses}

\section{5- and 10-Year Results}

Soraya M.R. Jonker, MD, Tos T.J.M. Berendschot, PhD, Annick E. Ronden, BSc, Isabelle E.Y. Saelens, MD, PhD, Noël J.C. Bauer, MD, PhD, Rudy M.M.A. Nuijts, MD, PhD

Purpose: To evaluate the long-term change in endothelial cell density (ECD) after the implantation of 2 types of rigid iris-fixated phakic intraocular lenses (plOLs) for the treatment of myopia and astigmatism.

Design: Prospective, clinical cohort study.

Participants: A total of 507 eyes of 289 patients receiving the Artisan Myopia or Artisan Toric (Ophtec B.V., Groningen, The Netherlands) iris-fixated pIOL for the treatment of myopia or astigmatism at the University Eye Clinic Maastricht as of January 1998.

Methods: A total of 381 myopic and 126 toric plOLs were implanted. Five- and 10-year follow-ups were completed by 193 and 127 eyes implanted with the myopic plOL and by 40 and 20 eyes implanted with the toric plOL, respectively.

Main Outcome Measures: Chronic endothelial cell (EC) loss, percentage of eyes with a decrease of $\geq 25 \%$ in ECD, and percentage of eyes with an ECD $<1500$ cells $/ \mathrm{mm}^{2}$.

Results: Chronic EC loss was calculated from 6 months postoperatively to the end of follow-up and showed an annual ECD decline of $48 \mathrm{cells} / \mathrm{mm}^{2}$ (standard error, 3.14) and $61 \mathrm{cells} / \mathrm{mm}^{2}$ (standard error, 6.30) in the myopic $(P<0.001)$ and toric $(P<0.001)$ groups, respectively, resulting in a total EC loss of $16.6 \%$ and $21.5 \%$ from 6 months to 10 years postoperatively, respectively. Ten years after implantation, ECD had decreased by $\geq 25 \%$ in $7.9 \%$ and $6.3 \%$, whereas ECD was $<1500$ cells $/ \mathrm{mm}^{2}$ in $3.9 \%$ and $4.0 \%$ in the myopic and toric groups, respectively. Explantation of the pIOL occurred in $6.0 \%$ in the myopic group and $4.8 \%$ in the toric group. Risk factors for increased EC loss were a shallow anterior chamber depth (ACD) $(P \leq 0.005)$ and a smaller distance between the central and peripheral pIOL edge to the endothelium $(P \leq 0.005)$.

Conclusions: A significant linear chronic EC loss was reported after implantation with myopic or toric iris-fixated pIOLs. A smaller ACD and smaller distance between pIOL edge and endothelium were risk factors for EC loss. Modification of preoperative age-related ECD thresholds is indicated to maintain an ECD that warrants safe future combined pIOL explantation and cataract surgery. Ophthalmology 2018;125:486-494 @ 2017 by the American Academy of Ophthalmology

See Commentary on page 495.

Implantation of phakic intraocular lenses (pIOLs), whether angle supported, iris fixated, or positioned in the posterior chamber, is associated with an accelerated decrease in endothelial cell density (ECD). ${ }^{1-9}$ The magnitude of endothelial cell (EC) loss after pIOL implantation surpasses the physiologic annual decrease of $0.6 \%$ as reported in 42 adults in a 1997 benchmark study. ${ }^{10}$ The importance of EC loss for assessing the safety of pIOLs was emphasized in 2006 when the French Health Products and Safety Agency (l'Agence Française de Sécurité Sanitaire des Produits de Santé [AFSSAPS]) withdrew the foldable angle-supported Vivarte pIOL (Ioltech S.A., Perigny, France) from the market because of excessive EC loss. More recently, the American Academy of Ophthalmology (AAO) Task Force has formulated guidelines that define the percentage of eyes with a total EC loss equal to or more than
$25 \%$ after 3 years as an end point for clinical investigation of a new pIOL. In addition, the AFSSAPS guidelines describe an ECD of less than 1500 cells $/ \mathrm{mm}^{2}$ as an explantation criterion. ${ }^{11,12}$ However, so far none of the published studies have used these newly established EC loss criteria as outcome measures. In this study, we applied these criteria as outcomes measures in our patient cohort of myopic and toric pIOLs that was followed over a 10-year period using the same specular microscope and ECD measurement protocols.

\section{Methods}

\section{Design}

From January 1998 to June 2016, 507 eyes of 289 patients received a myopic or toric iris-fixated pIOL implant at the University Eye 


\section{Jonker et al • Endothelial Cell Loss in Iris-Fixated Phakic IOLs}

Clinic Maastricht, Maastricht University Medical Center, The Netherlands. Patients were prospectively evaluated preoperatively and at 1 day, 1 week, and 1, 3, 6, and 12 months postoperatively in the first postoperative year. Regular follow-up continued with annual visits. The rigid myopic pIOL was implanted in 381 eyes of 209 patients, and 193 and 127 eyes completed the 5- and 10-year follow-ups, respectively. The rigid toric pIOL was implanted in 126 eyes of 80 patients, with 40 and 20 eyes completing the 5- and 10-year follow-ups, respectively.

The current study was performed in adherence to the tenets of the Declaration of Helsinki. The Maastricht University Medical Center Institutional Review Board stated that approval was not required for this study.

\section{Implantation Criteria}

Before pIOL implantation, patients had to be aged $\geq 18$ years and have a stable refraction for at least 2 years. Anterior chamber depth (ACD) from the corneal endothelium to the anterior plane of the crystalline lens had to be at least $2.8 \mathrm{~mm}$ with a maximal clear lens rise of $600 \mu \mathrm{m} .{ }^{1,13,14}$ Preoperative minimal ECD depended on age with $>2800$ cells $/ \mathrm{mm}^{2}$ required for patients aged 21 to 25 years, $>2650$ cells $/ \mathrm{mm}^{2}$ for patients aged 26 to 30 years, $>2400$ cells $/ \mathrm{mm}^{2}$ for patients aged 31 to 35 years, $>2200$ cells $/ \mathrm{mm}^{2}$ for patients aged 36 to 45 years, and $>2000$ cells $/ \mathrm{mm}^{2}$ in patients aged more than 45 years. $^{1,15}$

This article does not contain data of patients treated with irisfixated pIOLs in keratoconus or irregular astigmatism or patients treated with iris-fixated pIOLs after corneal transplantation. Data from a subset of patients from the present study were reported in previous studies. $^{16-19}$

\section{Phakic Intraocular Lenses and Surgical Technique}

The Artisan Myopia pIOL is a 1-piece, polymethyl methacrylate, rigid lens with a convex-concave optic and a total diameter of $8.5 \mathrm{~mm}$. The optic diameter is variable and depends on the required refractive correction; pIOLs from -1.0 to -15.5 diopters (D) are available in a $6.0-\mathrm{mm}$ optic diameter, whereas a $5.0-\mathrm{mm}$ optic diameter is available for pIOL powers from -1.0 to $-23.5 \mathrm{D}$.

The Artisan Toric pIOL is a 1-piece, polymethyl methacrylate, rigid lens with a convex-concave optic, a spherical power ranging from +14.0 to $-22.0 \mathrm{D}$, and a cylindrical power of up to $-7.5 \mathrm{D}$. The total diameter is $8.5 \mathrm{~mm}$ with an optic diameter of $5.0 \mathrm{~mm}$. Lens power calculations were performed by the manufacturer using the formula of van der Heijde et al. ${ }^{20}$

All surgeries were performed by the same surgeon (R.M.M.A.N.) at the University Eye Clinic Maastricht under general or local anesthesia. Previous reports by our group have described the surgical procedure and postoperative medication regimen. ${ }^{16-19}$

\section{Evaluation}

Preoperative examination consisted of subjective and cycloplegic refraction, Snellen uncorrected distance visual acuity (VA) and corrected distance VA measurements, and slit-lamp examination, including Goldmann applanation tonometry and fundoscopy. Additional measurements consisted of corneal topography (Orbscan [Bausch \& Lomb, Rochester, NY, USA], Pentacam HR [OCULUS Optikgeräte GmbH, Wetzlar, Germany], Sirius [Schwind eye-tech-solutions GmbH \& Co. KG, Kleinostheim, Germany]), biometry (A2500 [SonomedEscalon, New Hyde Park, NY, USA], IOLMaster [Carl Zeiss AG, Oberkochen, Germany]), anterior segment optical coherence tomography (OCT) (Visante [Carl Zeiss AG, Oberkochen, Germany]) and specular microscopy (NONCON ROBO PACHY SP9000 S/N PK1-1137; [Konan Medical Inc., Nishinomiya, Japan]). All preoperative measurements were performed 1 week after removal of soft contact lenses and 2 weeks after removal of rigid gas-permeable contact lenses.

From 2006 onward, OCT was used to perform preoperative pIOL simulation to measure the ACD, the vault between the pIOL and crystalline lens, the distance between the anterior pIOL and the endothelium, and the clear lens rise as reported previously. 1,13,14,18,21,22 Annual postoperative follow-up visits consisted of subjective refraction, Snellen uncorrected distance VA and corrected distance VA measurements, slit-lamp examination, tonometry, corneal topography, anterior segment OCT, and specular microscopy.

In respect of the known variation between specular microscopes and the influence of this variation on the correct calculation of EC loss, all eyes continued their measurements with the same specular microscope. ${ }^{23-26}$ Per protocol, the mean ECD in each eye was calculated by determining the mean of 3 consecutive measurements of 50 central ECs using the manual center-to-center method. ${ }^{27}$

\section{Outcome Measures}

The definitions of outcome measures were based on the recent guidelines of the AAO and AFSSAPS, describing the percentage of eyes reaching the AAO end point (i.e., EC loss $\geq 25 \%$ compared with the preoperative measurement) and AFSSAPS explantation criterion (i.e., ECD $<1500$ cells $/ \mathrm{mm}^{2}$ ). ${ }^{11,12}$ We calculated the mean ECD 5 and 10 years after pIOL implantation, as well as the annual EC loss. To adhere to the AAO-defined guidelines, we not only presented the percentage of eyes meeting the AAO-defined end point after 5 and 10 years but also added the percentage of eyes meeting this end point after 3 years. ${ }^{12}$

\section{Statistical Analysis}

Statistical analysis was performed using SPSS for Windows (version 23, IBM, Armonk, NY). All VA measurements were converted from Snellen VA to logarithm of the minimum angle of resolution VA before statistical analysis. Descriptive analyses were performed to compute mean and standard deviation ( \pm standard deviation) in primary outcome measures and preoperative characteristics. Longitudinal changes were analyzed using a linear mixed-model analysis with an eye identification number as a grouping variable and time as a covariate. The best fitted covariance structure was selected using the Bayesian information criterion. Similar to previous reports on EC loss, the effect of pIOL implantation on the endothelium (i.e., acute EC loss) was assessed from preoperatively to 6 months postoperatively, whereas long-term changes (i.e., chronic EC loss) were assessed from 6 months postoperatively to the end of follow-up. Kaplan-Meier and multivariate Cox regression analyses were performed to assess survival from implantation to the occurrence of the AAO-defined end point (i.e., total EC loss $\geq 25 \%$ ) and the AFSSAPS-defined explantation criterion (i.e., ECD $<1500$ cells $/ \mathrm{mm}^{2}$ ). $P$ values were considered significant if the $P$ value was $<0.05$.

\section{Results}

From January 1998 to June 2016, 381 eyes of 209 patients were implanted with the myopic pIOL and 126 eyes of 80 patients were implanted with the toric pIOL. Mean follow-up was $94.9 \pm 56.5$ months in the myopic group and $50.4 \pm 46.8$ months in the toric 
group. Baseline characteristics of both groups are depicted in Table 1.

After extensive parental consultation, 4 eyes of 3 patients younger than 18 years of age were implanted with a myopic pIOL because of a $-7.0 \mathrm{D}$ anisometropia in 1 eye of 1 patient (age 14 years) with contact lens intolerance, because of contact lens intolerance in 2 eyes of 1 patient (age 15 years) with a -30.0 and $-18.5 \mathrm{D}$ preoperative refraction, and to prevent amblyopia in 1 eye of a 5-year-old $-12.0 \mathrm{D}$ anisometropic and contact lens-intolerant patient. Between 1998 and 2006, there were no definitive thresholds formulated by the Netherlands Society for Refractive Surgery (Nederlands Gezelschap voor Refractie Chirurgie [NGRC]) with respect to preoperative ECD. ${ }^{15}$ As a result, myopic pIOLs were implanted in 16 eyes of 12 patients and toric pIOLs in 4 eyes of 4 patients with an ECD lower than 2000 cells $/ \mathrm{mm}^{2}$.

\section{Endothelial Cell Density}

The mean ECD preoperatively and at 6 months and 5 and 10 years postoperatively is reported in Table 2 and Figure 1. There was no significant acute EC loss from preoperatively to 6 months postoperatively in the myopic group $(P=0.35)$ or toric group $(P=0.59)$.

With respect to chronic EC loss, we found a mean annual ECD decline of 48 cells $/ \mathrm{mm}^{2}$ (standard error, 3.14) per year in the myopic group $(P<0.001)$ and a mean annual ECD decline of 61 cells $/ \mathrm{mm}^{2}$ (standard error, 6.30) per year in the toric group $(P<$ 0.001). By using these findings to compute the percentage of EC loss, from 6 months to 5 years postoperatively in the myopic and toric groups, these results equal a proportional EC loss of $7.9 \%$ and $10.2 \%$, and from 6 months to 10 years postoperatively these results equal a proportional EC loss of $16.6 \%$ and $21.5 \%$, respectively. When correcting for a physiologic EC loss of $0.6 \%$ per year, ${ }^{5,10}$ the pIOL-related total chronic EC loss from 6 months to 5 years is $5.2 \%$ and $7.5 \%$, and $10.9 \%$ and $15.8 \%$ from 6 months to 10 years in the myopic and toric groups, respectively. When performing a direct subgroup analysis, comparing ECD preoperatively and 5 and 10 years postoperatively, we found a total EC loss of $4.1 \%$ and $11.5 \%$ in the myopic group and $11.9 \%$ and $18.5 \%$ in the toric groups, respectively.

The AAO-defined end point of an EC loss $\geq 25 \% 3$ years after implantation was reached in $1.6 \%$ of eyes in the myopic and in $0.8 \%$ of eyes in the toric group. For 5 and 10 years after implantation, these proportions were $1.8 \%$ and $7.9 \%$, and $3.2 \%$ and $6.3 \%$ in the myopic and toric groups, respectively. The percentage of eyes that reached the AFSSAPS-defined explantation criterion of ECD $<1500$ cells $/ \mathrm{mm}^{2}$ after 5 and 10 years was $0.8 \%$ and $3.9 \%$ in the myopic group and $3.2 \%$ and $4.0 \%$ in the toric group, respectively.

Median survival time (i.e., time until $50 \%$ of eyes will reach the AAO-defined end point or AFSSAPS-defined explantation criterion) was 180 months in the myopic group and could not be calculated in the toric group because there were too few eyes reaching the defined end point or explantation criterion (Fig 2).

In 23 eyes of 16 patients $(6.0 \%)$ in the myopic group and 6 eyes of 5 patients $(4.8 \%)$ in the toric group, EC loss or corneal decompensation resulted in explantation of the pIOL after $11.9 \pm 2.7$ and $7.4 \pm 2.6$ years, respectively (Table 3). Only 1 myopic pIOL $(0.3 \%)$ was explanted because of EC loss within 5 years, and 4 eyes of 4 patients $(1.0 \%)$ required pIOL explantation because of EC loss within 10 years of pIOL implantation. Likewise, only 1 toric pIOL $(0.8 \%)$ was explanted because of EC loss within 5 years and in 4 eyes of 4 patients (3.2\%) within 10 years. Unfortunately, because of the small number of eyes requiring pIOL explantation because of EC loss, a median survival time (i.e., time until $50 \%$ of eyes requires explantation) could not be calculated (Fig 3).

\section{Risk Factors}

Additional analyses were performed to evaluate which eyes were at risk for an increased EC loss. Univariate risk factors for increased EC loss in a linear mixed model were smaller preoperative ACD $(P<0.001)$, smaller distance from the central pIOL edge to the endothelium $(P=0.008)$ and peripheral pIOL edge to the endothelium $(P=0.013)$, younger preoperative age $(P<0.001)$, and higher preoperative $\operatorname{ECD}(P=0.008)$. Based on the anatomy of the anterior chamber, the position of the pIOL induces a strong correlation between ACD and central or peripheral pIOL edge to the endothelium distance. Therefore, 3 different multivariate linearmixed models were fitted to the data including either the ACD, central or peripheral pIOL edge to the endothelium distance, and the earlier mentioned univariate risk factors. This resulted in 3 final simplified models: 1 model describing a lower preoperative age $(P=0.001)$ and smaller preoperative $\operatorname{ACD}(P<0.001)$ as risk factors and 2 models reporting only smaller central $(P=0.002)$ and peripheral $(P=0.003)$ pIOL edge to the endothelium as significant risk factors. The effects of changing age and ACD, and central or peripheral pIOL edge to the endothelium distance on EC loss are depicted in Tables 4 and 5 and Figure 4.

To assess which risk factors influenced survival, multivariate Cox regression analyses were performed. The effect of a risk factor on survival was expressed as a hazard ratio (HR), with an HR $>1$ or $<1$ indicating an increased or decreased probability of a shorter survival, respectively. All risk factors identified in the univariate linear mixed-model analyses were added to 3 different multivariate Cox regression models composed around either the ACD, central or peripheral pIOL edge to the endothelium distance. After excluding insignificant risk factors, smaller ACD (HR, 5.69; 95\% confidence interval $[\mathrm{CI}], 2.71-11.96 ; P<0.001)$, smaller central pIOL edge to the endothelium distance (HR, 5.35; 95\% CI, 2.50-11.46; $P<0.001$ ), and smaller peripheral pIOL edge to the endothelium distance (HR, 5.94; 95\% CI, 2.31-15.26; $P<0.001$ ) were identified as risk factors for reaching the AAO end point (i.e., $\geq 25 \%$ total EC loss) or AFSSAPS explantation criterion (i.e., ECD $<1500$ cells $/ \mathrm{mm}^{2}$ ). Similar results are reported with regard to survival until explantation, reporting smaller ACD (HR, 18.07 [95\% CI, 4.22-77.37], $P<0.001)$, smaller central pIOL edge to the endothelium distance (HR, 22.93 [95\% CI, 3.52-149.29], $P=$ 0.003 ), and smaller peripheral pIOL edge to the endothelium distance (HR, 24.44 [95\% CI, 2.85-209.87], $P=0.004$ ) as significant risk factors.

\section{Discussion}

Reporting long-term ECD and EC loss data in studies on pIOLs is important because it can provide data for establishing guidelines on risk assessment and follow-up strategies for implantation of pIOLs. In both the distant and recent past, a multitude of anterior chamber angle-supported and iris-fixated pIOLs have been taken off the market because of excessive EC loss and complications such as pupil ovalization and cataract formation. ${ }^{1,2,11,12}$ Subsequently, researchers and authorities have been pressed to formulate guidelines specifying safety criteria for implantation of anteriorchamber pIOLs. ${ }^{1,2,11,17,28-30}$ In the current study, we applied recently formulated criteria by the AAO Task Force and the AFSSAPS on EC analysis after pIOL implantation to a cohort of myopic and toric pIOL patients with a follow-up 
Jonker et al • Endothelial Cell Loss in Iris-Fixated Phakic IOLs

Table 1. Patient and Phakic Intraocular Lens Characteristics at Baseline (Mean \pm Standard Deviation)

\begin{tabular}{lcc}
\hline & Artisan Myopia & Artisan Toric \\
\hline Age, yrs & $41.2 \pm 10.7$ (range, 5.3 to 62.3$)$ & $38.8 \pm 11.4$ (range, 18.5 to 68.2$)$ \\
Ratio male/female, $\%$ & $35 / 65$ & $49 / 51$ \\
No. of eyes & 381 & 126 \\
No. of patients & 209 & 80 \\
MRSE, D & $-12.72 \pm 5.07$ (range, -30.50 to 0.00$)$ & $-6.52 \pm 8.52$ (range, -22.25 to 7.50$)$ \\
Cylinder, & $-1.22 \pm 0.80$ (range, -4.25 to 0.00$)$ & $-3.52 \pm 1.58$ (range, -8.50 to -1.00$)$ \\
CDVA, logMAR & $0.13 \pm 0.18$ (range, -0.18 to 1.70$)$ & $0.11 \pm 0.15$ (range, -0.18 to 0.70$)$ \\
IOP, mmHg & $14.7 \pm 3.2$ (range, 6.0 to 30.0$)$ & $15.1 \pm 3.3$ (range, 7.0 to 22.0$)$ \\
ACD, mm* & $3.68 \pm 0.34$ (range, 2.64 to 4.80$)$ & $3.49 \pm 0.35$ (range, 2.82 to 4.99$)$ \\
AXL, mm* & $28.18 \pm 2.20$ (range, 24.29 to 35.47$)$ & $25.68 \pm 3.40$ (range, 19.95 to 32.74$)$ \\
Implanted lens power & & \\
Sphere, D & $-13.15 \pm 3.83$ (range, -23.5 to -5.0$)$ & $-4.68 \pm 9.23$ (range, -19.5 to 11.5$)$ \\
Cylinder, D & NA & $-3.54 \pm 1.80$ (range, -8.0 to -1.0$)$
\end{tabular}

$\mathrm{ACD}=$ anterior chamber depth; $\mathrm{AXL}=$ axial length; CDVA = corrected distance visual acuity; $\mathrm{D}=$ diopters; $\mathrm{IOP}=$ intraocular pressure; $\log \mathrm{MAR}=$ logarithm of the minimum angle of resolution; MRSE = manifest refractive spherical equivalent; NA = not applicable.

*Measured from the corneal epithelium.

of 10 years. ${ }^{11,12}$ We believe that our patient cohort is unique in that over the entire 10-year follow-up period the same protocol and the same specular microscope were used, thereby decreasing the variability in data acquisition and increasing the reliability of our ECD data. ${ }^{23-26}$

\section{Endothelial Cell Density}

In this study, annual EC loss was calculated in cells $/ \mathrm{mm}^{2}$ per year using mixed-model linear regression analysis, enabling us to make full use of all gathered data from patients implanted with an iris-fixated myopic or toric pIOL, and calculating a generalized mean EC loss on the basis of the loss per patient (i.e., individual slopes).

Our results showed a linear decrease in ECD over a 10year period, without any signs of exponential EC loss or reaching a so-called plateau or stable ECD during this time. The results of these analyses were used to calculate the percentage of total EC loss and the percentage of total EC loss corrected for an annual physiologic loss of $0.6 \%$. Our 5-year results computed by linear mixed-model analysis are in line with previous studies reporting a total EC loss of $4.6 \%$ after 6 months ${ }^{4} ; 3.6 \%$ and $4.8 \%$ after 3 years $^{6,7} ; 1.5 \%, 2.07 \%, 12.5 \%$, and $13.4 \%$ after 4 years $^{3,7,9} ; 3.26 \%$ after 6 years $*^{5} 8.5 \%$ after 7 years; $*^{8}$ and $8.9 \%$ after 10 years* $\left(^{*}=\right.$ adjusted for $0.6 \%$ of annual physiologic loss). ${ }^{5}$
Key to understanding the difference between the 10-year results reported in this study and the literature is the ECD measurement method and data analysis. Contrary to the current study, a higher variability will be induced in the data of previous studies because different specular microscopes were used during follow-up, ${ }^{5,6}$ the ECD measurement method was altered during follow-up, ${ }^{8}$ the type of specular microscope used was not specified, $4,31,32$ the location of ECD measurements varied (i.e., centrally or peripherally), and the method of ECD measurements was not

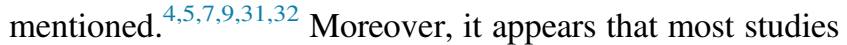
compared means or only used descriptive statistics instead of performing a longitudinal analysis, such as a mixedmodel linear regression analysis. ${ }^{3-7,31-33}$ Mixed-model linear regression analyses as performed in this study are especially useful when testing for significant changes over time (i.e., per year) and are to be preferred over tests assessing the mean differences between 2 individual time points (i.e., $t$ test). The results of the direct subgroup analysis, implying a nonlinear increase in EC loss between 5 and 10 years in the myopic group, should be interpreted only as an indication for continued follow-up rather than a definitive finding. Additional research on EC loss 15 or 20 years after pIOL implantation is required to put these results into perspective.

Over the past years, widely accepted guidelines have been implemented with regard to standardized reporting of

Table 2. Mean Endothelial Cell Density in Eyes Implanted with a Rigid Iris-Fixated Myopic or Toric Phakic Intraocular Lens (Mean \pm Standard Deviation)

\begin{tabular}{|c|c|c|c|c|}
\hline & No. Eyes & Artisan Myopia & No. Eyes & Artisan Toric \\
\hline \multicolumn{5}{|l|}{ ECD $\left(\right.$ cells $\left./ \mathrm{mm}^{2}\right)$} \\
\hline Preoperatively & 381 & $2670 \pm 365($ range, 1144 to 3753$)$ & 126 & $2695 \pm 359$ (range, 1760 to 3607 ) \\
\hline Acute: 6 mos & 267 & $2674 \pm 346$ (range, 1757 to 3584$)$ & 79 & $2665 \pm 368$ (range, 1623 to 3466 ) \\
\hline Chronic: 5 yrs & 193 & $2588 \pm 425$ (range, 478 to 3711 ) & 40 & $2270 \pm 406$ (range, 1296 to 3180 ) \\
\hline Chronic: 10 yrs & 127 & $2302 \pm 451$ (range, 556 to 3238 ) & 20 & $2009 \pm 475$ (range, 1178 to 2807 ) \\
\hline
\end{tabular}

$\mathrm{ECD}=$ endothelial cell density. 


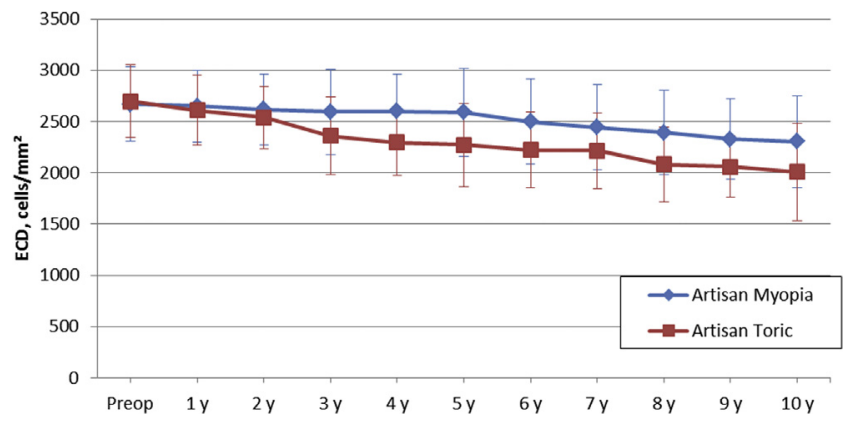

Figure 1. Mean endothelial cell density (ECD) from preoperatively to 10 years postoperatively in eyes implanted with rigid iris-fixated myopic $(\mathrm{n}=$ $381)$ and toric $(\mathrm{n}=126)$ phakic intraocular lenses (mean \pm standard deviation). $\mathrm{n}=$ number of eyes; $\mathrm{y}=$ years.

refractive and visual outcomes in studies on refractive surgery. ${ }^{34}$ However, no standardized guidelines exist for reporting ECD data after refractive surgery (e.g., implantation of phakic IOLs). In early 2017, the AAO Task Force published a guideline with regard to standardized reporting on EC loss in studies on new types of pIOLs. ${ }^{12}$ The key point of this guideline is to report the percentage of eyes with $\geq 25 \%$ EC loss 3 years after pIOL implantation. However, the guideline does not provide a recommendation with respect to the percentage of eyes with $\geq 25 \%$ EC loss that would warrant withdrawal of a specific pIOL from the market, nor does it make a statement whether any individual case with $\geq 25 \%$ EC loss warrants explantation of the pIOL in that particular eye. The AFSSAPS however, has recommended an ECD $<1500$ cells $/ \mathrm{mm}^{2}$ or a total EC loss of $30 \%$ as thresholds for pIOL explantation. ${ }^{11}$ This value of 1500 cells $/ \mathrm{mm}^{2}$ is selected because it is assumed that this ECD threshold will tolerate pIOL explantation and cataract surgery without compromising the integrity of the corneal endothelium in the long run. Given the difficult decision to explant pIOLs in individual cases of highly myopic patients who desire spectacle independency, a global consensus on explantation criteria would be highly desirable; therefore, we propose to compose an international working group that sets thresholds for EC loss that warrant pIOL explantation. Following the AAO guidelines, $1.6 \%$ and $0.8 \%$ of eyes in our myopic and toric groups reached the end point of EC loss $\geq 25 \%$ after 3 years, values that increased to $7.9 \%$ and $6.3 \%$ of eyes after 10 years. Given the young age of most patients undergoing a pIOL implantation, we believe that 10 years of endothelial safety data certainly should be included in the decision making for explantation of pIOLs. Pending international consensus, we have meanwhile adopted the threshold level of $<1500$ cells $/ \mathrm{mm}^{2}$ in our clinic as a criterion for $\mathrm{pIOL}$ explantation. In the present study, $0.8 \%$ and $3.9 \%$ of eyes from the myopic group had an ECD $<1500$ cells $/ \mathrm{mm}^{2}$ after 5 and 10 years, whereas these figures were $3.2 \%$ and $4.0 \%$ in the toric group, respectively. Endothelial cell loss resulted in pIOL explantation in 4 eyes of 4 patients in the myopic $(1.0 \%)$ and toric $(3.8 \%)$ groups after 10 years. In total, $6.0 \%$ of the implanted myopic and $4.8 \%$ of the

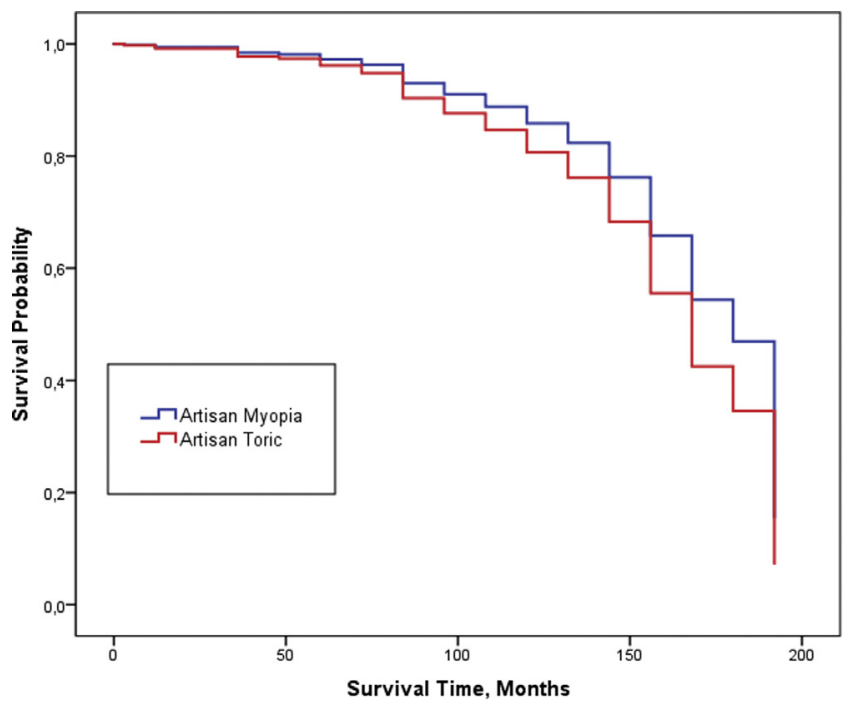

Figure 2. Survival curve for reaching the American Academy of Ophthalmology (AAO) end point (i.e., $\geq 25 \%$ decrease in endothelial cell density [ECD]) or French Health Products and Safety Agency (AFSSAPS) explantation criterion (i.e., ECD $<1500$ cells $/ \mathrm{mm}^{2}$ ) in eyes implanted with rigid iris-fixated myopic $(\mathrm{n}=381)$ and toric $(\mathrm{n}=126)$ phakic intraocular lenses. $\mathrm{n}=$ number of eyes.

implanted toric pIOLs had to be explanted because of EC loss after a mean of 11.9 and 7.4 years, respectively. Unfortunately, it was not possible to compare our results with previous reports because no previous study reported the percentage of eyes with an ECD $<1500$ cells $/ \mathrm{mm}^{2}$. Because of the small number of eyes requiring pIOL explantation due to EC loss, it also was not possible to compose a median survival describing how long it would take until $50 \%$ of eyes would reach an ECD $<1500$ cells $/ \mathrm{mm}^{2}$ or require $\mathrm{pIOL}$ explantation due to EC loss. This underlines earlier findings with anglesupported anterior chamber pIOLs in that it may take many years before the endothelial safety profile of a pIOL is known. ${ }^{35}$

In addition to presenting new guidelines on reporting ECD, the AAO guideline also refers to clause D.4.2 of American National Standards Institute (ANSI) standard Z80.13 (ANSI Z80.13 Phakic Intraocular Lenses standard [clause D.4.2]) for recommendations on how ECD measurements should be performed. Clause D.4.2 recommends 3 acceptable specular microscopy measurements of the central cornea to account for differences in the measurement location and issues an ECD measurement of at least 100 clearly identifiable cells using the center-to-center method. To decrease variance, measurements should be performed using the mean of multiple ECD measurements, while using the same noncontact specular microscope. In this study, all our ECD data are composed of the mean of 3 repeated specular microscopy measurements of the central cornea, measured with 1 noncontact specular microscope (Noncon Robo Pachy SP9000 S/N PK1-1137), while using the center-to-center method as specified in the referenced ANSI standard (ANSI Z80.13, clause D.4.2). However, clear identification of the advised number of 100 cells was not 
Jonker et al • Endothelial Cell Loss in Iris-Fixated Phakic IOLs

Table 3. Incidence and Indications of Phakic Intraocular Lens Explantations in Patients Implanted with Rigid Iris-Fixated Myopic $(\mathrm{n}=381)$ and Toric $(\mathrm{n}=126)$ Phakic Intraocular Lenses (Mean \pm Standard Deviation)

\begin{tabular}{|c|c|c|c|c|c|c|}
\hline & \multicolumn{3}{|c|}{ Artisan Myopia } & \multicolumn{3}{|c|}{ Artisan Toric } \\
\hline & $\begin{array}{l}\text { No. Eyes } \\
\text { [Patients] }\end{array}$ & $\begin{array}{l}\text { Ratio } \\
(\%)\end{array}$ & Time (Mos) & $\begin{array}{l}\text { No. Eyes } \\
\text { [Patients] }\end{array}$ & $\begin{array}{l}\text { Ratio } \\
(\%)\end{array}$ & Time (Mos) \\
\hline \multicolumn{7}{|l|}{ Explantation } \\
\hline Cataract & $44[30]$ & 11.55 & $100.4 \pm 33.1$ (range, 20.7-163.7) & $3[3]$ & 2.38 & $50.5 \pm 26.6$ (range, $13.8-75.8)$ \\
\hline EC loss & 14 [9] & 3.67 & $145.9 \pm 35.0($ range, $44.4-182.9)$ & $5[4]$ & 3.97 & $79.4 \pm 24.2$ (range, $48.6-121.7$ ) \\
\hline Cataract and EC loss & $4[3]$ & 1.05 & $157.6 \pm 23.5($ range, $120.0-179.7)$ & $1[1]$ & 0.79 & 136.9 \\
\hline Corneal edema* ${ }^{* \dagger}$ & $5[4]$ & 1.31 & $108.1 \pm 27.3($ range, $60.0-134.5)$ & $\mathrm{NA}$ & NA & NA \\
\hline High IOP & $4[2]$ & 1.05 & $53.2 \pm 26.5($ range, $25.7-80.3)$ & NA & NA & NA \\
\hline Anisometropia & $1[1]$ & 0.26 & 15.6 & NA & NA & NA \\
\hline Decentration & $1[1]$ & 0.26 & 1.4 & NA & NA & NA \\
\hline Recurrent retinal detachment ${ }^{\ddagger}$ & $1[1]$ & 0.26 & 82.8 & NA & NA & NA \\
\hline Unstable VA & $\mathrm{NA}$ & NA & NA & $1[1]$ & 0.79 & 10.6 \\
\hline \multicolumn{7}{|l|}{ Combined explantation } \\
\hline DSAEK* $*$ & $1[1]$ & 0.26 & 60.0 & NA & NA & NA \\
\hline $\mathrm{PK}^{\dagger}$ & $1[1]$ & 0.26 & 102.6 & NA & NA & NA \\
\hline Retinal surgery ${ }^{\ddagger}$ & $1[1]$ & 0.26 & 82.8 & NA & NA & NA \\
\hline
\end{tabular}

DSAEK = Descemet's stripping automated endothelial keratoplasty; $\mathrm{EC}=$ endothelial cell; $\mathrm{IOP}=$ intraocular pressure; NA = not applicable; $\mathrm{PK}=$ penetrating keratoplasty; VA = visual acuity.

*Corneal edema requiring DSAEK in 1 eye of 1 patient.

${ }^{\dagger}$ Corneal edema requiring $\mathrm{PK}$ in 1 eye of 1 patient.

${ }^{*}$ Recurrent retinal detachment requiring retinal surgery in 1 eye of 1 patient.

possible in a large number of measurements. ${ }^{12}$ It is our opinion that a measurement method of 50 instead of 100 contiguous cells is unlikely to significantly affect our results because we reported the mean of 3 central measurements performed on primarily healthy corneas, which decreases the possibility of misrepresentation of the data. We would like to highlight our doubts about the practical feasibility of marking 100 contiguous cells in 1 noncontact specular microscopic image, given the

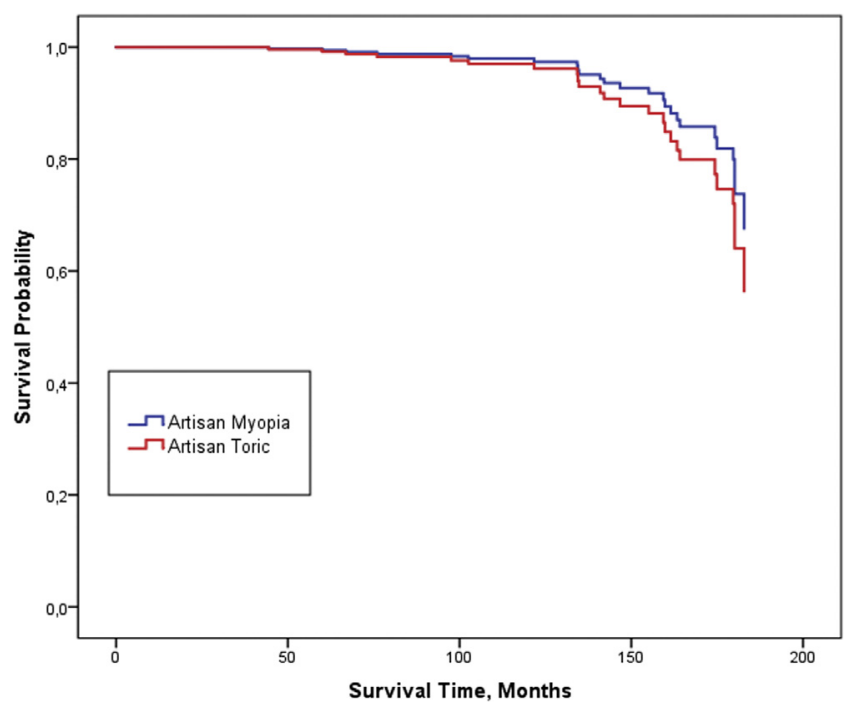

Figure 3. Survival curve for reaching endothelial cell (EC) loss-related phakic intraocular lens explantation in eyes implanted with rigid irisfixated myopic $(\mathrm{n}=381)$ and toric $(\mathrm{n}=126)$ phakic intraocular lenses. $\mathrm{n}=$ number of eyes. variation in image quality within 1 patient and between patients. The ANSI standard might press researchers in selecting cells that would not qualify as clearly identifiable, resulting in misrepresentation of ECD and morphology. This could be especially worrisome in studies reporting data on a small number of eyes with a short follow-up period because a small error can have a large influence on the data.

The ECD follow-up schedule of the AAO Task Force is in accordance with our past and current follow-up schedule and describes regular visits at $6,12,24$, and 36 months after pIOL implantation, whereas the NGRC guidelines strongly recommend patients to come in every other year. ${ }^{12,15} \mathrm{We}$ applied an annual follow-up pattern in the current study, as suggested by the AAO Task Force, and would suggest lifelong continuation on the basis of our 10-year results. Furthermore, the recently formatted guidelines recommend additional visits with a 4- to 6-month interval in eyes with $>20 \%$ EC loss or an ECD $<1500$ cells $/ \mathrm{mm}^{2}$, a policy we agree with and implement in current practice. ${ }^{12}$

\section{Risk Factors}

In line with previous studies, our results showed a smaller distance between the central and peripheral pIOL edge and the endothelium, as well as a smaller preoperative ACD as risk factors for increased EC loss. ${ }^{8,17,18,30}$ The effects of ACD and distance between central and peripheral pIOL edge to the endothelium on both EC loss and survival can be explained by the close proximity of the pIOL to the endothelium, resulting in a higher risk of (intermittent) contact between pIOL and corneal endothelium, ultimately leading to cell damage and increased EC loss. ${ }^{10,36}$ The multivariate linear-mixed model focused around the preoperative ACD 
Table 4. Changes in Endothelial Cell Loss over 5 and 10 Years with Altering Preoperative Age and Anterior Chamber Depth in

Eyes Implanted with Iris-Fixated Myopic $(n=381)$ or Toric $(\mathrm{n}=126)$ Phakic Intraocular Lenses

\begin{tabular}{|c|c|c|c|c|}
\hline & \multirow[b]{3}{*}{$(\mathrm{mm})$} & \multicolumn{3}{|c|}{ Preoperative Anterior Chamber Depth* } \\
\hline & & Mean -2 SD & Mean & Mean +2 SD \\
\hline & & 2.94 & 3.64 & 4.34 \\
\hline \multicolumn{5}{|l|}{ EC loss: 5 yrs } \\
\hline Preoperative age & (yrs) & & & \\
\hline Mean -2 SD & 18.7 & $17.4 \%$ & $12.3 \%$ & $6.7 \%$ \\
\hline Mean & 40.6 & $15.3 \%$ & $9.5 \%$ & $3.3 \%$ \\
\hline Mean +2 SD & 62.5 & $12.6 \%$ & $6.1 \%$ & $\mathrm{NA}^{\dagger}$ \\
\hline \multicolumn{5}{|l|}{ EC loss: 10 yrs } \\
\hline Preoperative age & (yrs) & & & \\
\hline Mean $-2 \mathrm{SD}$ & 18.7 & $34.9 \%$ & $24.5 \%$ & $13.4 \%$ \\
\hline Mean & 40.6 & $30.5 \%$ & $19.0 \%$ & $6.5 \%$ \\
\hline Mean +2 SD & 62.5 & $25.3 \%$ & $12.3 \%$ & $\mathrm{NA}^{\dagger}$ \\
\hline
\end{tabular}

$\mathrm{NA}=$ not applicable; $\mathrm{SD}=$ standard deviation.

*Measured from the corneal epithelium to the anterior pole of the crystalline lens.

${ }^{\dagger}$ Gain in ECD.

also identified a younger age as a risk factor for EC loss, but this effect was not described in the literature or reciprocated in any of our other analyses. With every diopter of accommodation, the anterior pole of the crystalline lens moves into the direction of the endothelium by $30 \mu \mathrm{m}$, resulting in a similar decrease in ACD. It is known that the accommodative capacity is greater in younger patients, ranging up to $10 \mathrm{D}$, whereas it decreases gradually until reaching an accommodative capacity of $0 \mathrm{D}$ at approximately age 65 years. $^{35}$ This fluctuating ACD in younger patients could induce a shallower ACD during the day, attributing to the effect of ACD in the described analysis.

Table 5. Changes in Endothelial Cell Loss over 5 and 10 Years with Altering Distance from the Central or Peripheral Phakic Intraocular Lens Edge to the Corneal Endothelium in Eyes Implanted with Iris-Fixated Myopic $(n=381)$ or Toric $(n=126)$ Phakic Intraocular Lenses

\begin{tabular}{|c|c|c|c|c|}
\hline & \multirow[b]{3}{*}{$(\mathrm{mm})$} & \multicolumn{3}{|c|}{$\begin{array}{l}\text { Central pIOL Edge to the } \\
\text { Endothelium Distance }\end{array}$} \\
\hline & & Mean -2 SD & Mean & Mean +2 SD \\
\hline & & 1.60 & 2.17 & 2.74 \\
\hline EC loss: 5 yrs & & $13.5 \%$ & $10.3 \%$ & $6.7 \%$ \\
\hline EC loss: 10 yrs & & $27.0 \%$ & $20.5 \%$ & $13.4 \%$ \\
\hline
\end{tabular}

Peripheral pIOL Edge to the Endothelium Distance

\begin{tabular}{|c|c|c|c|c|}
\hline & \\
\hline & & Mean -2 SD & Mean & Mean +2 SD \\
\hline & $(\mathrm{mm})$ & 1.00 & 1.55 & 2.10 \\
\hline EC loss: 5 yrs & & $13.0 \%$ & $10.2 \%$ & $6.9 \%$ \\
\hline EC loss: 10 yrs & & $26.0 \%$ & $20.3 \%$ & $13.8 \%$ \\
\hline
\end{tabular}

$\mathrm{pIOL}=$ phakic intraocular lens; $\mathrm{SD}=$ standard deviation.

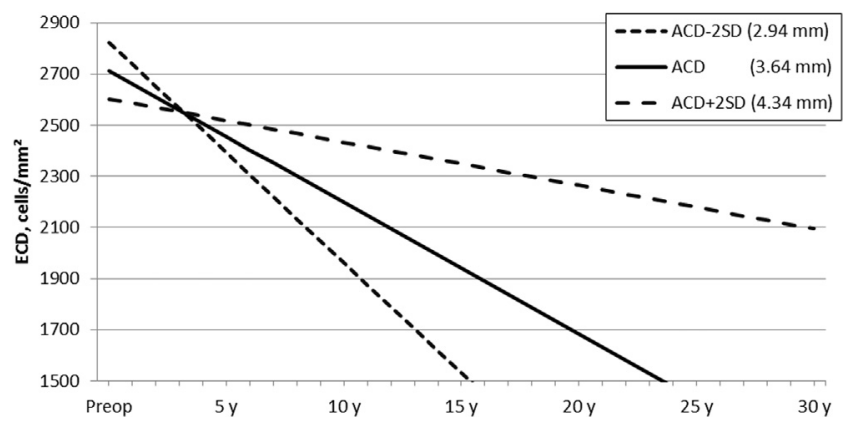

Figure 4. Differences in linear decrease in endothelial cell (ECD) with changing preoperative anterior chamber depths (ACDs) in eyes implanted with rigid iris-fixated myopic $(n=381)$ and toric $(n=126)$ phakic intraocular lenses. $\mathrm{n}=$ number of eyes; $\mathrm{SD}=$ standard deviation; $\mathrm{y}=$ years.

Our survival analyses confirmed the significant roles of ACD, central, and peripheral pIOL edge to the endothelium distance on the described ECD-related outcome measures: AAO end point (i.e., $\geq 25 \%$ total EC loss) or AFSSAPS explantation criterion (i.e., ECD $<1500$ cells $/ \mathrm{mm}^{2}$ ) and pIOL explantation due to EC loss.

\section{Recommendations}

This study reported a total chronic EC loss of $16.6 \%$ and $21.4 \%$ from 6 months to 10 years in the myopic and toric groups, respectively, as well as $6.0 \%$ and $4.8 \%$ explantations due to EC loss, respectively. Our analyses confirm those of previous studies describing a smaller, crowded anterior chamber as a risk factor for EC loss. ${ }^{8,17,18}$

Application of the recently defined AAO end points 10 years after implantation showed $7.9 \%$ of myopic and $6.3 \%$ of toric eyes with a total EC loss $\geq 25 \%$. This is in line with a linear annual ECD decline of 48 cells $/ \mathrm{mm}^{2}$ and 61 cells/ $\mathrm{mm}^{2}$ in the myopic and toric groups, respectively. Our data showed the importance of preoperative ACD as a risk factor for increased EC loss and suggests the need for a higher threshold of preoperative age-related ECD to ensure the cornea is healthy enough to endure future cataract surgery and pIOL explantation. In our study cohort, patients undergoing pIOL explantation due to cataract formation had a mean age of $56.1 \pm 8.5$ in the myopic group and $57.1 \pm 5.9$ in the toric group (data on file). The mean age at pIOL implantation was 41.2 years in the myopic group and 38.8 in the toric group, meaning that a patient at the time of implantation would need a preoperative ECD of at least 2215 cells $/ \mathrm{mm}^{2}$ in the myopic group and 2616 cells $/ \mathrm{mm}^{2}$ in the toric group to maintain a safe ECD of $\geq 1500 \mathrm{cells} / \mathrm{mm}^{2}$ until cataract surgery is required. However, an 18-year-old patient scheduled for pIOL implantation should have a preoperative ECD of at least 3310 cells $/ \mathrm{mm}^{2}$ in the myopic group and 3885 cells/mm $/ \mathrm{mm}^{2}$ in the toric group to maintain an ECD of $\geq 1500$ cells $/ \mathrm{mm}^{2}$ until cataract surgery is performed.

On the basis of our study, we recommend scheduling patients with pIOLs for annual follow-up visits to evaluate 
the corneal endothelium. International guidelines are needed to set thresholds for pIOL explantation in case of increased EC loss.

\section{Acknowledgments}

Special thanks to Bjorn Winkens, PhD, and Gerard van der Linden, $\mathrm{BSc}$, for their valuable contributions to this study.

\section{References}

1. Guell JL, Morral M, Kook D, Kohnen T. Phakic intraocular lenses part 1: historical overview, current models, selection criteria, and surgical techniques. J Cataract Refract Surg. 2010;36:1976-1993.

2. Kohnen T, Kook D, Morral M, Guell JL. Phakic intraocular lenses: part 2: results and complications. J Cataract Refract Surg. 2010;36:2168-2194.

3. Menezo JL, Cisneros AL, Rodriguez-Salvador V. Endothelial study of iris-claw phakic lens: four year follow-up. J Cataract Refract Surg. 1998;24:1039-1049.

4. Dick HB, Alio J, Bianchetti M, et al. Toric phakic intraocular lens: European multicenter study. Ophthalmology. 2003;110: 150-162.

5. Tahzib NG, Nuijts RM, Wu WY, Budo CJ. Long-term study of Artisan phakic intraocular lens implantation for the correction of moderate to high myopia: ten-year follow-up results. Ophthalmology. 2007;114:1133-1142.

6. Stulting RD, John ME, Maloney RK, et al. Three-year results of Artisan/Verisyse phakic intraocular lens implantation. Results of the United States Food and Drug Administration clinical trial. Ophthalmology. 2008;115:464-472.e1.

7. Guell JL, Morral M, Gris O, et al. Five-year follow-up of 399 phakic Artisan-Verisyse implantation for myopia, hyperopia, and/or astigmatism. Ophthalmology. 2008;115:1002-1012.

8. Saxena R, Boekhoorn SS, Mulder PG, et al. Long-term followup of endothelial cell change after Artisan phakic intraocular lens implantation. Ophthalmology. 2008;115:608-613.e1.

9. Titiyal JS, Sharma N, Mannan R, et al. Iris-fixated intraocular lens implantation to correct moderate to high myopia in AsianIndian eyes: five-year results. J Cataract Refract Surg. 2012;38:1446-1452.

10. Bourne WM, Nelson LR, Hodge DO. Central corneal endothelial cell changes over a ten-year period. Invest Ophthalmol Vis Sci. 1997;38:779-782.

11. Bernard P, Fournier M. Definitive stop of marketing, product recall and follow-up of implanted patients. Presbyopic intraocular lenses NEWLIFE/VIVARTE PRESBYOPIC. Agence Française de Sécurité Sanitaire des Produits de Santé (AFSSAPS), 2007; v. 2016.

12. MacRae S, Holladay JT, Hilmantel G, et al. Special Report: American Academy of Ophthalmology Task Force Recommendations for Specular Microscopy for Phakic Intraocular Lenses. Ophthalmology. 2017;124:141-142.

13. Baikoff G. Anterior segment OCT and phakic intraocular lenses: a perspective. J Cataract Refract Surg. 2006;32:1827-1835.

14. Baikoff G, Bourgeon G, Jodai HJ, et al. Pigment dispersion and Artisan phakic intraocular lenses: crystalline lens rise as a safety criterion. J Cataract Refract Surg. 2005;31:674-680.

15. Aalders-Deenstra V, Bartels $M$, Beerthuizen $J$, et al. Consensus Refractie Chirurgie. 3rd ed: Nederlands Gezelschap voor Refractie Chirurgie (NGRC); 2013.
16. Doors M, Eggink FA, Webers CA, Nuijts RM. Late-onset decentration of iris-fixated phakic intraocular lenses: a case series. Am J Ophthalmol. 2009;147:997-1003.e1-e2.

17. Doors M, Berendschot TT, Webers CA, Nuijts RM. Model to predict endothelial cell loss after iris-fixated phakic intraocular lens implantation. Invest Ophthalmol Vis Sci. 2010;51: 811-815.

18. Doors M, Cals DW, Berendschot TT, et al. Influence of anterior chamber morphometrics on endothelial cell changes after phakic intraocular lens implantation. J Cataract Refract Surg. 2008;34:2110-2118.

19. Visser N, Berendschot TT, Bauer NJ, Nuijts RM. Vector analysis of corneal and refractive astigmatism changes following toric pseudophakic and toric phakic IOL implantation. Invest Ophthalmol Vis Sci. 2012;53:1865-1873.

20. van der Heijde GL, Fechner PU, Worst JG. [Optical consequences of implantation of a negative intraocular lens in myopic patients]. Klin Monbl Augenheilkd. 1988;193: 99-102.

21. Guell JL, Morral M, Gris O, et al. Evaluation of Verisyse and Artiflex phakic intraocular lenses during accommodation using Visante optical coherence tomography. J Cataract Refract Surg. 2007;33:1398-1404.

22. Baumeister M, Buhren J, Kohnen T. Position of anglesupported, iris-fixated, and ciliary sulcus-implanted myopic phakic intraocular lenses evaluated by Scheimpflug photography. Am J Ophthalmol. 2004;138:723-731.

23. Cheung SW, Cho P. Endothelial cells analysis with the TOPCON specular microscope SP-2000P and IMAGEnet system. Curr Eye Res. 2000;21:788-798.

24. Ding X, Huang Q, Zheng Y, et al. Measurement area and repeatability of semiautomated assessment of corneal endothelium in the Topcon specular microscope SP-2000P and IMAGEnet system. Cornea. 2012;31:1111-1118.

25. Prinz A, Varga J, Findl O. Reliability of a video-based noncontact specular microscope for assessing the corneal endothelium. Cornea. 2007;26:924-929.

26. van Schaick W, van Dooren BT, Mulder PG, VolkerDieben HJ. Validity of endothelial cell analysis methods and recommendations for calibration in Topcon SP-2000P specular microscopy. Cornea. 2005;24:538-544.

27. McCarey BE, Edelhauser HF, Lynn MJ. Review of corneal endothelial specular microscopy for FDA clinical trials of refractive procedures, surgical devices, and new intraocular drugs and solutions. Cornea. 2008;27:1-16.

28. Alfonso JF, Lisa C, Abdelhamid A, et al. Three-year follow-up of subjective vault following myopic implantable collamer lens implantation. Graefes Arch Clin Exp Ophthalmol. 2010;248:1827-1835.

29. Doors M, Berendschot TT, Hendrikse F, et al. Value of preoperative phakic intraocular lens simulation using optical coherence tomography. J Cataract Refract Surg. 2009:35:438-443.

30. Shajari M, Scheffel M, Koss MJ, Kohnen T. Dependency of endothelial cell loss on anterior chamber depth within first 4 years after implantation of iris-supported phakic intraocular lenses to treat high myopia. J Cataract Refract Surg. 2016;42: 1562-1569.

31. Guell JL, Vazquez M, Malecaze F, et al. Artisan toric phakic intraocular lens for the correction of high astigmatism. Am J Ophthalmol. 2003;136:442-447.

32. Budo C, Hessloehl JC, Izak M, et al. Multicenter study of the Artisan phakic intraocular lens. J Cataract Refract Surg. 2000;26:1163-1171. 
33. Benedetti S, Casamenti V, Benedetti M. Long-term endothelial changes in phakic eyes after Artisan intraocular lens implantation to correct myopia: five-year study. J Cataract Refract Surg. 2007;33:784-790.

34. Reinstein DZ, Archer TJ, Randleman JB. JRS standard for reporting astigmatism outcomes of refractive surgery. J Refract Surg. 2014;30:654-659.
35. Baikoff G, Lutun E, Ferraz C, Wei J. Static and dynamic analysis of the anterior segment with optical coherence tomography. J Cataract Refract Surg. 2004;30:18431850.

36. Armitage WJ, Dick AD, Bourne WM. Predicting endothelia cell loss and long-term corneal graft survival. Invest Ophthalmol Vis Sci. 2003;44:3326-3331.

\section{Footnotes and Financial Disclosures}

Originally received: May 17, 2017.

Final revision: July 10, 2017.

Accepted: August 8, 2017

Available online: September 18, $2017 . \quad$ Manuscript no. 2017-957

University Eye Clinic Maastricht, Maastricht University Medical Center, Maastricht, The Netherlands.

Presented at the XXXIV European Society of Cataract and Refractive Surgeons congress, September 10-14, 2016, Copenhagen, Denmark.

Financial Disclosure(s):

The author(s) have made the following disclosure(s): N.J.C.B.: Consultant, lecturer, financial support - Alcon; Consultant, lecturer - Bausch \& Lomb; Financial support - Ophtec.

R.M.M.A.N.: Consultant, lecturer, financial support - Alcon; Consultant Asico, Bausch \& Lomb, TheaPharma; Financial support - Abbott, CarlZeiss, Gebauer, HumanOptics, Ophtec, Oculentis.

HUMAN SUBJECTS: The Maastricht University Medical Center Institutional Review Board stated that approval was not required for this study. This study was performed in adherence to the tenets of the Declaration of Helsinki.

\section{Author Contributions:}

Conception and design: Jonker, Berendschot, Saelens, Bauer, Nuijts

Data collection: Jonker, Ronden, Saelens, Nuijts

Analysis and interpretation: Jonker, Berendschot, Nuijts

Overall responsibility: Jonker, Berendschot, Ronden, Saelens, Bauer, Nuijts Abbreviations and Acronyms:

AAO = American Academy of Ophthalmology $\mathbf{A C D}=$ anterior chamber depth; AFSSAPS $=$ French Health Products and Safety Agency/l'Agence Française de Sécurité Sanitaire des Produits de Santé; ANSI = American National Standards Institute; $\mathbf{C I}=$ confidence interval; $\mathbf{D}=$ diopters; $\mathbf{E C}=$ endothelial cell; $\mathbf{E C D}=$ endothelial cell density; $\mathbf{H R}=$ hazard ratio; NGRC $=$ Netherlands Society for Refractive Surgery/Nederlands Gezelschap voor Refractie Chirurgie; OCT $=$ optical coherence tomography; pIOL $=$ phakic intraocular lens; $\mathbf{S D}=$ standard deviation; VA $=$ visual acuity.

Correspondence:

Soraya M.R. Jonker, MD, University Eye Clinic Maastricht, Maastricht University Medical Center, PO Box 5800, 6202 AZ, Maastricht, The Netherlands. E-mail: soraya.jonker@mumc.nl.

\section{Pictures \& Perspectives}

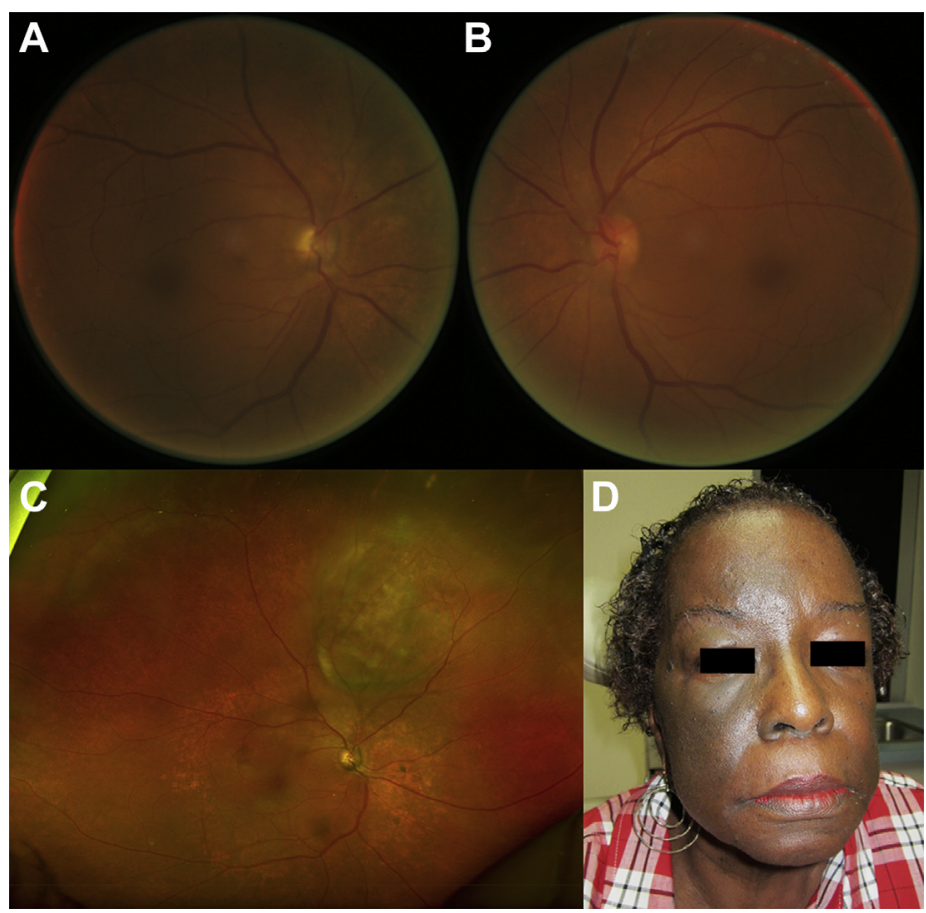

Oculodermal Melanocytosis, Darker Complexion, Choroidal Melanoma: A Missed Clue

A 68-year-old African-American woman with known history of an abnormally pigmented right optic nerve head was referred for a choroidal mass. Examination of the right eye demonstrated numerous pigmented scleral patches, diffuse iris thickening with mammillations, a hyperpigmented optic disc with slightly asymmetric hyperpigmentation of the choroid compared with her left eye (Fig 1A-B), and a choroidal melanoma (Fig 1C). External examination with bright illumination revealed subtly increased skin pigmentation of the right hemiface (Fig 1D). The patient's oculodermal melanocytosis had been undiagnosed because of her darker skin complexion, possibly delaying diagnosis of choroidal melanoma; her asymmetric optic nerve pigmentation was a misunderstood clue.

\footnotetext{
MEERa Ramakrishnan, MD ${ }^{1}$

ROBIN VORA, MD ${ }^{2}$

Michael I. SEIDER, MD ${ }^{2,3}$

${ }^{1}$ Kaiser Foundation Hospital, Oakland, California; ${ }^{2}$ Department of Ophthalmology, The Permanente Medical Group, Oakland, California; ${ }^{3}$ Department of Ophthalmology, University of California, San Francisco, California
} 